\title{
OBSERVATIONS ON THE SENSITIVITY OF THE HAEMOLYTIC SYSTEM IN COMPLEMENT- FIXATION TESTS
}

\author{
BY \\ H. M. RICE \\ From the Department of Pathology, General Hospital, Nottingham
}

(RECEIVED FOR PUBLICATION JULY 16, 1955)

The development, in recent years, of optimalproportions techniques has made possible a great increase in the sensitivity of complement-fixation tests, without any loss of specificity. This is particularly true of the Wassermann reaction. Since 1949 Price (1949a, 1949b, 1950a, 1950b) has shown that the performance of the test is greatly improved when the reagents are used in optimal amounts. His technique is applicable to any complement-fixation test, and gives highly reproducible results, unaffected by changes in the batches of reagents, since all antigens, for example, are titrated before issue for use at the optimal dilution. Standardization of results is therefore possible not merely from day to day in any one laboratory but between all departments using Price's (Whitechapel) technique. Quantitative tests have thus acquired more than a purely local significance, and are of much greater value in the control of therapy.

Price (1949a) has stressed that optimal-proportions techniques can only be used when the complement is stable, and has paid tribute to Richardson's (1941) work on the preservation of complement. Price has dealt with the antigen (1950a), complement (1949b), and serum dilutions (1950b), and Price and Wilkinson (1947) with the strength of the red-cell suspension, in the Wassermann reaction. Other variables are the method of sensitization of the haemolytic system, and the time interval between sensitization and use. Some serologists insist on the agitation of the cells during sensitization, while others consider this unimportant. The haemolytic system may be used immediately after sensitization, after standing at room temperature or at $4^{\circ} \mathrm{C}$. for several hours, or even after overnight storage in the refrigerator. Alternatively, cells and amboceptor may be mixed and then kept at $4^{\circ} \mathrm{C}$. until half an hour before use sensitization is completed in the $37^{\circ} \mathrm{C}$. water-bath. The American custom of adding cell suspension and haemolysin separately during the actual performance of the test, as in Kolmer's method, does not appear to obtain in this country.

With relatively insensitive techniques, employing two or more M.H.D. of complement as the test dose, some latitude in the preparation and use of the haemolytic system is permissible. But with more critical techniques, such as Price's in which the complement dose (at $1 \frac{1}{4}$ M.H.D.) is near the 9 theoretical minimum, considerable differences may result from minor variations in technique, especially in quantitative tests.

In most departments using the Whitechapel technique it is customary to make screen tests in $\stackrel{\mathbb{Q}}{\Omega}$ the morning and quantitative tests, as indicated, $\overrightarrow{\vec{P}}$ the same afternoon. The haemolytic system is $\frac{\circ}{3}$ usually left at room temperature in the interval. $\bar{\partial}$ Such was our practice initially. It was, however, soon observed that sera giving weakly positive results, i.e., showing partial haemolysis, in the morning were not infrequently found negative $\frac{5}{3}$ when the quantitative test was performed in the afternoon. Series of parallel quantitative tests were, therefore, made to study the effects of variations in the method of preparation, storage, $\frac{\text { ㄱ }}{2}$ and the time lag before use of the sensitized cell $>$ suspension, in both the Wassermann reaction and the gonococcal complement-fixation test.

\section{Methods}

The Price (Whitechapel) technique was employed for all complement-fixation tests.

Wassermann Reaction.-All sera were tested by a screen Wassermann reaction (W.R.) and screen Price's? + precipitation reaction (P.P.R.) in the morning. If the $\square$ screen P.P.R. was positive, a quantitative P.P.R. was carried out as a routine. Quantitative W.R.s were $\stackrel{\mathbb{D}}{\Omega}$ performed on those sera giving a positive W.R. but $\mathbb{\mathbb { D }}$ negative P.P.R. in the screen tests. Quantitative $\frac{\varrho}{\sigma}$ tests were performed by the doubling-dilution technique in eight tubes (giving serum dilutions from 8 
neat to 1 in 128). Occasional sera, mainly from cases of treated syphilis exhibiting serological oscillation, were examined quantitatively by both W.R. and P.P.R.

Gonococcal Complement-fixation Tests.-Screen tests were also made in the mornings and quantitative tests in the afternoons, as indicated.

The Haemolytic System.-Preliminary washing of the sheep cells, which were always between one and four days old, was carried out on the evening before the test. After final washing on the test morning the double-strength suspension $(5 \%)$ was prepared, using Price's haematocrit, and an equal volume of doublestrength (12 M.H.D.) haemolysin added, with thorough mixing. Sensitization was carried out in the waterbath at $37^{\circ} \mathrm{C}$. for 30 minutes simultaneously with the first incubation of the complement titration. The complement titre was thus always determined with freshly sensitized cells.

As a routine the cells were not agitated during sensitization. But since Price recommends bubbling air through the suspension by means of a suctionpump, a series of tests was performed in parallel on "bubbled" and "unbubbled" suspensions prepared simultaneously.

Time-lag before Use.-In routine screen tests the haemolytic system was used one and a half hours after preparation, and had been standing at room temperature in the interval. The residue became the "old" preparation for the afternoon's experiments, and was used when it was between five and six hours old. "New" cells were freshly prepared for the parallel tests, and were used immediately.

The third type, "split" cells, consisted of a portion of the morning suspension taken immediately after the haemolysin had been added and kept at $4^{\circ} \mathrm{C}$. until the afternoon, when sensitization was completed in the water-bath at the same time as the new cells. The period of refrigeration equalled the standing time for the old suspension each day (five to six hours).

\section{Material}

The sera were from hospital and clinic (both antenatal and V.D.) patients. All the results reported are from unselected, consecutive routine tests over a period of 13 months.

The tests necessitated doubling dilutions, in parallel or in triplicate, on all sera. To minimize experimental error all dilutions were made by the same two workers.

Samples of serum insufficient for all three titrations were tested with old and new suspensions. This was the only form of selection throughout the series. As only routine sera were used the number tested varied from day to day; it never exceeded 12 and was usually about six.

One hundred and seventy-five sera in the main series of 250 and 260 out of the final total of 400 sera were from known cases of syphilis $(70 \%$ and $65 \%$ respectively).

\section{Results}

Experiment 1 : Agitation of Cells during Sensitization.-Fifty sera were tested in parallel with "bubbled" and "unbubbled" sensitized cell suspensions. Twenty-seven sera showed complete agreement and in no instance was a difference in titre of more than one tube $(100 \%)$ recorded. Twelve sera showed a higher titre with bubbled, and 11 with unbubbled cells. Since by the time the last of these 50 sera had been tested some hundreds of parallel tests in the main series had been made, showing marked differences in readings (up to four tubes), it was concluded that the performance of the haemolytic system is not affected by agitation during incubation in the water-bath. The results are summarized in Table I.

TABLE 1

50 SERA TESTED WITH BUBBLED AND UNBUBBLED CELLS

\begin{tabular}{llc|c}
\hline & & Number & Difference in Titre \\
\hline Agreement & $\cdots$ & 27 & - \\
B $>$ U & $\cdots$ & 12 & $\frac{2}{2}$ \\
U $>$ B $\ldots$ & $\cdots$ & 11 & \\
\hline
\end{tabular}

Experiment 2: Comparison of New and Old Suspensions (400 Tests). - Initially, it was thought that the preparation of doubling dilutions in parallel would be a sufficient tax on the technicians concerned. After some 45 tests, however, they themselves suggested performing the tests in triplicate, thereby effecting a great saving in time. With the addition of sera yielding sufficient for two but not all three titrations, as the experiments continued, numbers in the new v. old $(\mathrm{N} / \mathrm{O})$ series increased steadily. By the time the 250 triplicate examinations had been made, the $\mathrm{N} / \mathrm{O}$ series totalled nearly 400 . The remaining few were tested after the main series was complete in order to yield a round number.

It soon became evident that more sera gave higher titres with the new cells than with old, and that a difference of more than one tube was not uncommon ( 23 out of 400 sera, or $5.75 \%$ ). Fourteen tests showed a four-fold difference (two tubes): seven, eight-fold (three tubes): and two, 16-fold (four tubes). One hundred and fifteen sera showed a difference of one tube, so that a total of 138 sera $(34.5 \%)$ gave a higher titre with new than with old cells.

On the other hand, only 33 sera $(8.25 \%)$ showed a higher titre with the old cells, the difference never exceeding two-fold.

The results are summarized in Table II. 
TABLE II

400 SERA TESTED WITH NEW AND OLD CELLS

\begin{tabular}{|c|c|c|c|c|c|c|c|c|}
\hline & \multicolumn{6}{|c|}{ Difference in Titre } & \multicolumn{2}{|c|}{ Agreement } \\
\hline & $\times 2$ & $\times 4$ & $\times 8$ & $\times 16$ & Total & $\%$ & Total & $\%$ \\
\hline $\begin{array}{l}\mathbf{N}>\mathbf{O} \\
\mathbf{O}>\mathbf{N}\end{array}$ & $\begin{array}{r}115 \\
33\end{array}$ & 14 & $\begin{array}{r}7 \\
-\end{array}$ & $\underline{2}$ & $\begin{array}{r}138 \\
33\end{array}$ & $\begin{array}{c}34.5 \\
8.25\end{array}$ & 229 & 57.25 \\
\hline
\end{tabular}

Experiment 3: Simultaneous Comparison of New, Split, and Old Cell Suspensions (250 Tests). -Forty-seven sera had been tested in duplicate with split and old cells before this experiment started, and had failed to show the marked difference in performance found with new and old suspensions. This separate split $\mathrm{v}$. old $(\mathrm{S} / \mathrm{O})$ series was therefore discontinued and the $\mathrm{S} / \mathrm{O}$ results now reported are limited to those of the main series.

New $v$. Old $(N / O)$. - The results are generally similar in proportion and extent to those reported above, of which they form a part. New gave a higher titre than old with 84 sera (33.6\%). In 67 the difference was two-fold; in 10, four-fold; in five, eight-fold ; and in two, 16 -fold. Only 28 sera $(11.2 \%)$ showed a higher titre with old than with new cells, and then only of one tube (Table III).

New v. Split $(N / S)$. - Seventy-five sera $(30 \%)$ gave a higher reading with the new cells, 58 of one tube, 12 of two tubes, four of three tubes, and one of four tubes. Thirty-three sera (13.2\%) gave a higher titre with split cells, all of one tube only (Table III).

TABLE III

250 SERA TESTED IN TRIPLICATE WITH NEW, SPLIT, AND OLD CELL SUSPENSIONS

\begin{tabular}{|c|c|c|c|c|c|c|c|c|c|}
\hline & \multicolumn{6}{|c|}{ Difference in Titre } & \multicolumn{2}{|c|}{ Agreement } \\
\hline & & $\times 2$ & $\times 4$ & $\times 8$ & $\times 16$ & Total ! & $\%$ & Total & $\because$ \\
\hline $\mathbf{N} \mathbf{O}$ & $\begin{array}{l}\mathbf{N}>\mathbf{O} \\
\mathbf{O}>\mathbf{N}\end{array}$ & $\begin{array}{l}67 \\
28\end{array}$ & 10 & $\underline{5}$ & $\underline{2}$ & $\begin{array}{l}84 \\
28\end{array}$ & $\begin{array}{l}33.6 \\
11.2\end{array}$ & 138 & $55 \cdot 2$ \\
\hline $\mathbf{N} / \mathbf{S}$ & $\begin{array}{l}\mathbf{N}>\mathbf{S} \\
\mathbf{S}>\mathbf{N}\end{array}$ & $\begin{array}{l}58 \\
33\end{array}$ & 12 & 4 & 1 & $\begin{array}{l}75 \\
33\end{array}$ & $\begin{array}{l}30.0 \\
13.2\end{array}$ & 142 & $56 \cdot 8$ \\
\hline S:O & $\begin{array}{l}\mathbf{S}>\mathbf{O} \\
\mathbf{O}>\mathbf{S}\end{array}$ & $\begin{array}{l}48 \\
45\end{array}$ & $\begin{array}{l}9 \\
3\end{array}$ & 二 & 二 & $\begin{array}{l}57 \\
48\end{array}$ & $\begin{array}{l}22.8 \\
19.2\end{array}$ & 145 & 58 \\
\hline
\end{tabular}

Split $v$. Old $(S / O)$.- In this series a striking difference was noted. Not only were numbers much more even, but this was the only series in which old cells gave higher titres by more than one tube. Split gave higher readings than old with 57 sera $(22.8 \%), 48$ of one tube and nine of two tubes. Old gave the higher readings with 48 sera $(19.2 \%), 45$ of one tube and three of two tubes (Table III).
In all three series similar numbers of readings showed complete agreement:

$$
\begin{array}{lll}
\text { N/O approximately } & 55 \% \\
\text { N/S } & \text { " } & 57 \% \\
\text { S/O } & 58 \% \text { (see Table III) }
\end{array}
$$

Experiment 4 : Complement Titrations.-Routine complement titrations are always made before the Wassermann reaction is performed. To determine whether the use of old cells would appreciably affect the titre of the complement, a series of parallel titrations of complement (preserved by Richardson's method) was made with new and old cells. Four such titrations, on different days, showed slight differences. With old cells there tended to be a slight tailing-off, with partial haemolysis in one more tube in some rows so that the reading was less clear cut than with new cells, although the titre of the complement was not affected.

Experiment 5 : Gonococcal Complement Fixation Tests.- Sera from known cases of gonorrhoea are not routinely tested in our laboratory, and in our experience titres greater than 1 in 8 are rare with the V.D.R.L. antigen. Marked differences in titre, similar to those in the Wassermann reactions, were therefore not expected, and did not occur. A series of 80 sera was, however, tested with new and old suspensions in parallel to check the applicability of our findings to a complement-fixation test using a specific antigen. Results numerically similar to the Wassermann series were recorded, although no difference in titre of more than $100 \%$ occurred. New exceeded old with 18 sera, while old exceeded new with eight. In the other 54 titrations there was complete agreement.

\section{Discussion}

The object of the experiments was to investigate the effects of certain variations in the methods of preparation and storage of the haemolytic system. Their scope was limited by the necessity of carrying out routine procedures at the same time; but the evidence obtained does lead to certain conclusions.

In any serological test involving a doublingdilution technique, a difference of $100 \%$ (one tube) between two results is not considered significant. But, with any large series, the results should show approximately the same scatter about the mean, if the error be due to technical and random causes. In Fig. 1 the information contained in Table III is presented in graphic form. Comparing the $\mathrm{N} / \mathrm{O}$ and $\mathrm{N} / \mathrm{S}$ results it is apparent that $\mathrm{N}$ exceeds both $\mathrm{S}$ and $\mathrm{O}$, not only in numbers but in degree. The scatters show a shift to the right, 


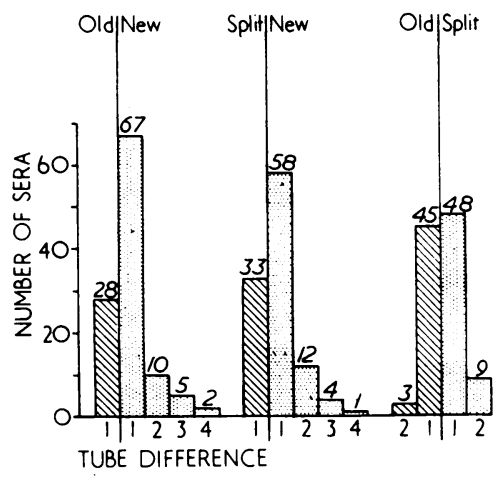

FIG. 1

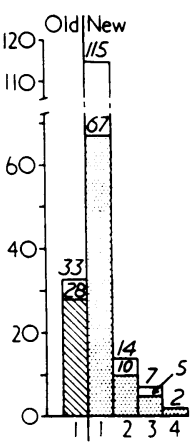

FIG. 2

FIG. 1.-Results of 250 tests in triplicate with new, split, and old cells. New exceed split and old in both numbers and degree, but split and old cells show similar results.

Fig. 2. - Results of 400 tests in duplicate, with new and old cells emphasizing the marked disproportion of the curve. The figures for the triplicate series are superimposed.

but another significant fact is that there is no numerical gradation of the left side of either diagram, which rises abruptly from the base line. $\mathrm{N}$ is exceeded by $\mathrm{S}$ and by $\mathrm{O}$ in approximately the same number of tests, but never in greater degree than one tube, so that the curve is unbalanced.

With the $\mathrm{S} / \mathrm{O}$ series the picture is different. Not only are numbers very similar on the two sides, but there is evidence of a more normal scatter, with the same amplitude of variation from the mean. This was to be expected, since the $\mathrm{N} / \mathrm{S}$ and $\mathrm{N} / \mathrm{O}$ curves are so similar.

When the $\mathrm{N} / \mathrm{O}$ graph is expanded to include the full 400 results, the result obtained in the N.S.O. series is confirmed and, indeed, even exaggerated. In Fig. 2 the $\mathrm{N} / \mathrm{O}$ figures for the 250 triplicate titrations are shown superimposed on the figures of the full 400 tests to demonstrate this effect.

Analysis of the higher discrepancies (eight-fold and 16-fold differences in titre) shows that in the N.S.O. series the seven $\mathrm{N} / \mathrm{O}$ and five $\mathrm{N} / \mathrm{S}$ results were from nine sera on six different days. One serum showed a four-tube difference with both $S$ and $O$ cells: a second gave a three-tube difference with $\mathrm{S}$ and four tubes with $\mathrm{O}$. The other eight-fold discrepancies showed $\mathrm{S}$ readings to exceed $\mathrm{O}$ by two tubes twice, and $\mathrm{O}$ to exceed $\mathrm{S}$ by two tubes once, the other sera giving no difference greater than two-fold between $\mathrm{S}$ and $\mathrm{O}$. The two further three-tube differences in the $\mathrm{N} / \mathrm{O}$ series occurred on different days, so that eight different sets of suspensions, but a total of only 11 sera, were involved. These high discrepancies were not therefore isolated and unrelated phenomena.
The results in the gonococcal complementfixation test series were insufficient in number and degree to warrant the drawing of conclusions: but what evidence there is supports the findings in the Wassermann experiments.

The parallel titration of complement with new and old suspensions also demonstrated the increased tendency to lysis of the cells on standing. This finding was not pursued because complement titrations are always made with freshly prepared cell suspensions.

The evidence all leads to the conclusion that there is some qualitative difference between new and both split and old cells, whereas there is no significant difference in the performance of the latter two suspensions. Both $\mathrm{S}$ and $\mathrm{O}$ cells are more readily lysed than $N$, and therefore, to ensure that quantitative results are accurate, it is necessary always to use new cells. The reason for the increasing tendency to lysis of sensitized erythrocytes, and the nature of the change which occurs on standing, have yet to be explained. The temperature at which the cells stood (room temperature or $4^{\circ} \mathrm{C}$.) and the timing of sensitization in the water-bath made no significant difference in the experiments reported.

The mode of preparation of the suspension was investigated because the Whitechapel technique specifies agitation of the cells during the period of sensitization. The writer had not done this for many years, when using the Harrison-Wyler, Harrison-Wyler-Lacey (Rice, 1950), and Whitechapel techniques, because there seemed to be no theoretical or practical basis for it. The 50 parallel titrations performed support this view (Table I).

\section{Summary and Conclusions}

Two hundred and fifty unselected consecutive routine sera, on which quantitative Wassermann tests were required, were tested in triplicate by the Price (Whitechapel) tecinnique, using three different haemolytic systems. "New" suspensions $(\mathrm{N})$ were freshly prepared immediately before use ; "old" suspensions (O) had stood at room temperature for five to six hours ; and "split" suspensions $(\mathrm{S})$ were stored for five to six hours at $4^{\circ} \mathrm{C}$., immediately after adding the haemolysin, and sensitized at the same time as the new suspensions. The sera were from both hospital and clinic cases. Specimens sufficient for only two tests were titrated with new and old suspensions, and the $\mathrm{N} / \mathrm{O}$ series finally totalled 400 .

The results showed that, while there was no significant difference between split and old cells, 
both were more readily lysed than new, in approximately similar numbers and degree. In the main series $\mathrm{N}$ exceeded $\mathrm{O}$ in 84 instances $(33.6 \%)$, of which 10 were four-fold, five eight-fold and two 16-fold differences. Old suspensions exceeded $\mathrm{N}$ in $28(11.2 \%)$. New suspensions exceeded $S$ with 75 sera $(30.0 \%), 12$ four-fold, four eight-fold, and one 16-fold. Split suspensions exceeded $\mathrm{N}$ in 33 instances (13.2\%). Between $\mathrm{S}$ and $\mathrm{O}$ there was no marked difference. Split suspensions exceeded $\mathbf{O}$ in 57, of which nine were four-fold and none greater. Old suspensions exceeded $S$ in 45 , with three of four-fold difference. In the full $\mathrm{N} / \mathrm{O}$ series, $\mathrm{N}$ gave higher readings with 138 sera $(34.5 \%)$, of which 14 were four-fold, seven eightfold, and two 16-fold. Old suspensions exceeded $\mathrm{N}$ in 33 cases $(8.25 \%)$.

Limited supporting evidence was obtained from 80 gonococcal complement-fixation test titrations with $\mathrm{N}$ and $\mathrm{O}$ cells. This series was examined for the sake of studying reactions with a specific antigen.

Complement titrations with old cells also demonstrated their increasing tendency to lysis compared with new cells. Readings were not so clear cut. Fifty parallel titrations showed no difference between cell suspensions agitated during sensitization and those not agitated.
It is concluded that sensitized cell suspensions show an increasing tendency to lysis on standing, and that in order to obtain strictly comparable quantitative results in complement-fixation tests using optimal-proportions techniques, it is necessary always to use a haemolytic system that has been freshly prepared.

The writer wishes to express his thanks to Mr. T. O. Roach, Miss S. G. Barr, A.I.M.L.T., and Miss J. L. White for their technical assistance.

\section{Addendum}

Gonococcal Complement-fixation Tests.-Additional tests have increased the total in this series to 200 , and two sera have exhibited a four-fold difference in titre, new cells giving the higher readings in each instance.

The full results were: $\mathrm{N}$ exceeded $\mathrm{O}$ with 55 sera (53 two-fold and two four-fold), while $O$ exceeded $\mathrm{N}$ with 25 (two-fold only). The other 120 sera showed agreement.

Nine of the 200 sera showed titres above $1 / 8$, the highest recorded being 1/64.

REFERENCES

Price, I. N. O. (1949a). Brit. J. vener. Dis., 25, 67.

(1949b). Ibid., 25, 157.

(1950a). Ibid., 26, 33.

(1950b). Ibid., 26, 172.

- and Wilkinson, A. E. (1947). Ibid., 23, 124

Rice, H. M. (1950). J. roy. Army med. Cps, 95, 146.

Richardson, G. M. (1941). Lancet, 2, 696. 